\title{
In transition: Collection building at the National Gallery of Modern Art in New Delhi
}

\author{
Arnika Ahldag \\ Associate Curator at the Museum of Art and Photography in Bengaluru \& PhD Candidate at the \\ School of Arts and Aesthetics, Jawaharlal Nehru University. ORCID: 0000-0002-1369-0392. \\ Email: arnika.ahldag@map-india.org
}

\begin{abstract}
The National Gallery of Modern Art (NGMA) in New Delhi stores a collection of about 17,000 artworks dating back to 1850. After the establishment of the NGMA in 1954 on the behest of India's first Prime Minister Jawaharlal Nehru to adequately store his collection of paintings of the Indian modernist and his friend Amrita Shergil, the collection was built up over 60 years by successive directors and their personal likings and peers.
\end{abstract}

Keywords: exhibition history, colonialism, Indian art

\section{In transition: Collection building and public display of the National Gallery of Modern Art}

In the most recent times, the museum's landscape in India has undergone major changes and shifts in the administering bodies. This is especially dramatic in case of museums, that had taken first steps to become a site of engagement for the public and revitalised in terms of its projects and visitors in the recent past, such as the National Museum and the National Handicrafts and Handlooms Museum in New Delhi. The government seems to be unable to grasp these signs of turnarounds. The museums and Akademis in India are under a direct mandate of the government of India. Leading positions sometimes remain vacant or are filled with bureaucrats who have hardly an interest. At the same times they are places of controversies.

In the recent history of art exhibitions, especially since 1945, since documentation and biennales are established arenas for exhibitions concepts, they have been under massive changes. There has also been a discourse on this topic, whether about the visual space of the room, discussed by Brian O' Doherty in "Inside the White cube" or curatorial concepts. From mainly history or genre focused exhibitions, art history in exhibitions was no longer told only in a chronological manner but more formalist concerns driven and through a new generation of "exhibition makers", such as Harald Szeemann and Rudi Fuchs among many others. The exhibition was thought through in a new way and through which even the institution that hosted the exhibitions was seen in a new light. The term 'archive' is widely used in contemporary cross-disciplinary discourse and covers a wide range of consignations, such as books, letters and art among many others. With The Archaeology of Knowledge published in 1969, Michel Foucault was the first theorist who wrote about the archive. Foucault's archive is not a physical space and differs from the conventional definition of an archive. His description of the archive is both, the "system of utterability" and the "law of what can be said". The archive does not reproduce but produces meaning and it is an instrument of power and authority, 
which in many ways can be disposed on museums as well. As a centre of production of meaning, Foucault's theory on the archive claims that the storage, organization, and redistribution of information are never passive or innocent; they always inform political and historical discourse.

If Foucault removed the archive from its physical space and theoretical framework, Jacques Derrida drew his arguments upon psychoanalysis and Freud's last house which became an archive and a museum. According to Derrida, we not only need archives, but we also burn for them. Jacques Derrida talks in the Introduction to Archive Fever. A Freudian Impression ${ }^{\prime \prime}$ about the localisation of the archive. According to him, an archive is a place that shelters memory. Archives - both national and individual - are memory factories, and memory holds meaning, which seems to be the main concern of theorists since the 1990s. For both, Foucault and Derrida, the archive cannot be seen as a passive repository. In fact, according to their theory, it shapes and controls the way history is read, which in turn shapes our political reality. The archive has become symbolic for the ways in which we construct and organize our histories- officially, collectively, and personally. It has also become a site of contestation, a theoretical space within which we can challenge the notion of historical positivism and the power structures created in archivisation.

If exhibitions are the sites where the artworks from the collection meet their publics, in the context of postcolonial India we notice a general absence of systematic public collections and only very few academic art history departments, exhibitions are more than just sites of display and interaction. Curated exhibitions are driven by institutional demands, and art writing accompanying them, have become the primary sites of art historical construction.

In the recent past there has been an increasing interest in exhibition history as a field of research. The London based research and publishing organisation Afterall, founded in 1998, published a series of critical analysis of contemporary art exhibitions starting in 2010, called Exhibition Histories. It was launched in collaboration with the Academy of Fine Arts, Vienna, the Van Abbemuseum, Eindhoven and with support from Mudam, Luxembourg. Exhibition Histories is currently published in association with the Center for Curatorial Studies at Bard College. Central Saint Martins in London together with Afterall, offer a postgraduate course that examines the history of contemporary art through key developments in the exhibition form.

In India, not institutionalised but several researchers have conducted projects in the past that dealt with exhibition history. Vidya Shivadas', who's research initially started with Mapping the Field of Art Criticism in India, Post Independence under a research grantee of Art Asia Archive, 2009 worked extensively on the NGMA and Lalit Kala Akademi exhibitions since Independence.

Archival material such as exhibition publications and newspaper article have been sighted for this article. The National Archives and Archaeological Service of India Archive provide access to rare documents until the 1960s, such as letters between the Ministry and the first director of the NGMA, Hermann Goetz, which contain information about the establishment of the museum and its structure. The Lalit Kala Akademi Library and the library and documentation center at the NGMA host a collection of rare catalogues and magazines.

Geeta Kapur's exhibition "Hundred years" was photo documented by Ram Rahman and the images are available online in the Asia Art Archive. For the exhibitions of the second period, this article is based on newspaper reviews, catalogue texts and interviews with Geeta Kapur and Rajeev Lochan, but also SK Saini, the former keeper of the NGMA from 1972 to the late 90s, who remains engaged with the institution by giving drawing classes every Sunday.

But where does the interest in exhibition histories come from and what can we extract from it? Bruce Altshuler states ${ }^{\mathrm{iii}}$ that the interest in exhibition histories might have evolved through the interest of the so called 'new' art history in context-specific and socio-historical approaches. One the one hand this 
refers to the foundation of new biennials and institutions for the exhibition of contemporary art, the expansion of the art market with its countless gallery shows and art fairs, as well as the increasing temporalization of the museum. A critical or artistic engagement with the collection has become almost a necessity for any museum. While these approaches are always based on the permanent collection, the forms of presentation increasingly resemble those of the temporary exhibition, replacing the supposedly rigid, authoritative and atemporal collection display.

In the case of the NGMA we look at a history of inclusion and exclusion, starting from the collection, but often reflected in the exhibitions. If national museums play a role in forming national identity, through interpreting history and culture and in promoting national agendas, which place finds Modernism in the history loaded repository of a gallery of modern art? Andreas Huysseniv has advanced the term "modernism at large," by which he refers to "cross-national cultural forms that emerge from the negotiation of the modern with the indigenous, the colonial, and the postcolonial in the 'non-Western' world." Over the last sixty years, modern Indian art has produced its own narrative, examined by scholars like Partha Mitter, in his publications Much maligned monsters, 1977, Art and Nationalism in colonial India, 1994 and The triumph of modernism, 2007. Tapati Guha- Thakurta The Making of a New "Indian" Art, 1995. All these publications serve as an analysis of the transformations that occurred in the art and aesthetic values of Bengal during the colonial and nationalist periods. Geeta Kapur's When was modernism, 2000 does not merely focus on the beginnings of modernism but examines the engagement in Indian art with the 'traditional', the 'modern', and the dialogue between nationalism and internationalism, and globalization.

\section{The establishment of a gallery for modern art}

The need for a National Gallery of Indian art was first suggested by the artist led All India Fine Arts and Crafts Society (AIFACS) for the Capital Complex in 1930 which was repeatedly rejected by the government. ${ }^{v}$ Already in the 1930s the two brothers, and founding members of AIFACS, Barada and Sarada Ukil organized a series of exhibitions of Indian art abroad. Their proposal for a museum contained detailed plans of galleries to represent art from different regions and princely states in India. Additionally, they were trying to set up a public fund to raise money for this project, as well as gathering support from the princely rulers, wanting to make them patrons. In 1946 AIFACS organized the First International Contemporary Art Exhibition in Delhi but could not keep up with their premises. The Bombay based All India Association of Fine Arts, and the All India Academy of Fine Arts, Calcutta became strong opposing agencies and started fighting among each other for setting up an institution for Indian art. ${ }^{\mathrm{vi}}$

At a conference in Calcutta in 1949, a Central Advisory Board was formed in order to set up a National Gallery, as well as the National Museum and three Akademis under the National Commission for Cooperation with UNESCO. This was again mentioned in the first volume of Roopa-Lekha, New Delhi's first art journal published by the AIFACS, where it says: "The chief objectives of the Society are: (i) to foster knowledge and love of art among the people of India and ultimately, (ii) to establish a National Art Gallery, and (iii) an Academy of Indian Art in the Imperial city of New Delhi."

In 1947, the Central Government had founded an art purchase committee to manage an art purchase fund to collect objects for the National Museum. The institution was meant to compile pre-modern art, from 2500 BC to 1857, a collection of the nation's cultural heritage. This can be understood as the young government's vision of a nation untouched by the colonizers to strengthen the new national identity, through the idea that the nation had already existed in a hoary past.

Significant for the late 1940s and 1950s was, that the cultural policy of the Indian government had a strong interest in the conservation of archeological sites and material and crafts, for which purpose colonial institutions such as Archeological Survey of India and the Anthropological Survey of India were 
reinforced. At that time this was not undertaken for contemporary art until Prime Minister Nehru's support came in.

The necessity for an institution, or moreover a facility for the storage of art works, appeared even more urgent in 1948: Dr. Victor Egan, Amrita Sher-Gil's Hungarian husband was now offering 33 paintings by the artist to the Ministry of Education, which was then in charge of cultural institutions. Amrita Sher-Gil had passed away in 1941. In return he requested a payment of Rs. 50.000 and the permission to practice medicine in India. viii Amrita Sher-Gil's paintings did not fit into the collection of the National Museum and though the government was eager on collecting national art treasures, it had no provision for the purchase of modern art. Therefore, a new committee and a new budget needed to be allocated. But the issue was an urgent matter, and the Ministry of Education requested the Ministry of Finance to provide them with the needful to execute Dr. Egan's monetary request. The Ministry of Finance, however, refused, based on a directive of the Prime Minister to "avoid all unnecessary expenditure". ix At the same time, knowing about Dr. Egan's offer to the government, Amrita's father Umrao Singh also offered a large body of work to the government, under the precondition, that the government also acquires the husband's collection: "They serve along with her early works to show the development of her art and talent... But if her later works are not actually acquired by our nation, then what good will the old-style work, which she herself did not value, be." ${ }^{\prime \prime}$

Nehru himself took up the issue, together with the first Minister of Education Maulana Kalam Azad, and promised Dr. Egan the requested amount of Rs. 50.000. The money was taken from the National Museum funds and reduced its budget in half for the year. Dr. Egan was allowed to build a hospital in Uttar Pradesh and Amrita Sher-Gil's inheritance was the first step towards a state-collection of modern art. The paintings were stored at the Central Asian Antiquities Museum and shown occasionally at UNESCO meetings at the Parliament House.

In 1953, in addition to Amrita's works, a collection of 66 paintings, sketches and drawings by Abanindranath Tagore were offered to the government for purchase. Pratima Tagore, Abanindranath's sister living in Santiniketan, offered her collection of 66 works of her brother to the government. The committee's bid of 15000 rs was rejected by her, whereupon Surendranath Kar, director of Kala Bhavana at Visva-Bharati advised her to sell each painting for the cost of 500rs (33000rs for 66 works). The case was picked up by $\mathrm{Dr}$ BC Roy, Chief Minister of West Bengal, who appealed to Maulana Abdul Kalam Azad to purchase the paintings to avoid them getting sold out of the country or getting dispersed in private collections. Dr Roy suggested a round sum of 30000rs and offered to make an allowance of 10000rs on behalf of the West Bengal Government to which Maulana Azad agreed and provided the remaining sum of 20000rs. Among the 161 paintings handed over to National Gallery of Modern Art at the time of its inauguration, Sher-Gil and Tagore's paintings would comprise more than half of the Museum's collection. The purchase of SherGil's paintings was the beginning of systematic acquisitions of modern art works for the National Gallery of Modern Art. When categorized, organized, and framed by the Museum's authoritative narratives, this body of works would become central to the formation of a canon of modern Indian art. For example, while the 33 paintings that the government acquired from Egan, along with another 33 paintings donated by SherGil's father, formed an important part of the Museum's collection, Sher-Gil's prominence within the Museum's core collection was challenged by precisely the same number of works by the Bengal School artist Abanindranath Tagore, acquired between 1950 and 1954. Furthermore, Abdur Rahman Chughtai was represented by ten paintings while Jamini Roy and Nandalal Bose by eight paintings each. ${ }^{\text {.i }}$

The National Gallery of Modern Art finally opened its doors at the Jaipur House, the former winter residence of the Maharaja of Jaipur, on 29 March 1954, under the administration of the government of India and under a direct mandate by the government. The choice to establish the Gallery in an already existing building might have been made on the grounds of financial issues. 
5 | In transition: Collection building at the National Gallery of Modern Art in New Delhi

At its inaugural ceremony Dr. Humayun Kabir, at that time the secretary of the Ministry of Education, stated that Delhi could not establish its claim as a metropolitan city till it had a National Gallery of Modern Art, a museum, a theatre and a library. ${ }^{\text {xii }}$ Two weeks earlier the Sahitya Akademi was founded, "India's National Academy of Letters", an institution to promote Indian literature and to set grounds for a literary dialogue, supporting regional languages as well as English. Later in the same year, on 5 August, the twin institution, the Lalit Kala Akademi was founded to encourage practices in the visual arts through national and international exhibitions, archival projects and publications.

In these years, many more institutions were founded to build up a basis for research and preservation. In the 1950s and 1960s a large number of institutes and initiatives were set up, such as the National School of Drama, the Institute of Advanced Studies in Shimla, the National Institute of Design and the Jawaharlal Nehru fellowship program. These institutions were meant to mark a break with the postcolonial consciousness and to lead the new Nation state into a new direction.

\section{A House for the National Gallery}

The Jaipur House was designed by Francis Bloomfield and built in 1936 as a summer residence for the Maharaja of Jaipur. Its floor plan resembles the shape of a butterfly and it has a dome in the centre. The architectural idea is based on Lutyen's concept of the Central Hexagon, and together with other princely potentates like Bikaner and Hyderabad House it revolved around the India Gate.

The Gallery opened with an exhibition of Indian sculptures, laid out in five rooms of the Jaipur house showing 65 works of 31 artists, like Debi Prasad Roy Chowdhury, Ram Kinkar Baij, Sankho Chaudhuri, Dhanraj Bhagat and Sarbari Roy Chowdhury. This exhibition had been curated by Hermann Goetz and remained on view, even after he left the institution.

The initial objective of the museum was the acquisition and preservation of art works from 1850 onwards, mainly paintings, graphics and sculptures and later also photographs.

\section{The early years of the NGMA - Hermann Goetz}

Hermann Goetz, a scholar and museologist from Germany became the museum's first director in 1954. During the First World War he had been interested in the Ottoman Turks and later he widened his interests to Iran and subsequently India in the age of the Mogul Emperors. He researched Indian miniature paintings in terms of ethnographical questions, e.g. the customs usages of the mogul empire. In the 1930s he was the curator at the Kern Institute for Archaeology and Indian History at Leiden University. He received a grant to work in India, where he interned during the second world war. Initially his task was to explore the history and art of the Punjab Hill States and the Indian Himalayas. The outcome was a comprehensive study on "The Early Wooden Temples of Chamba", in addition to numerous essays on miniature paintings. ${ }^{\text {xiii }}$ In 1940 the Maharaja of Baroda appointed Goetz as the Director of the Baroda Museum and Picture Gallery, following the renowned German art historian Ernest Cohn-Wiener, who had been in charge of the Picture Gallery from 1934 until 1939, when he wished to leave India again for health reasons. In Baroda he organised the picture gallery with a rich collection of European Paintings. He also added a collection of Indian art as well as western artists working in India. In 1943 he founded the Bulletin of the Baroda Museum and joined the University of Baroda as Honorary Professor. ${ }^{\text {xiv }}$

In 1954 he came to Delhi to become the first curator of the NGMA. The initial attempt in building up a collection was rather in quantity and not in quality, the institution was a storehouse for entire collections of artist's works, which had been gifted to the gallery. Hermann Goetz came in to change that and to build up a systematic collection, with works representing an artist's œuvre. 
He asked the Ministry of Education in a letter dated on the $18^{\text {th }}$ March 1953 to change the procedure of asking the purchase committee of the National Art Treasures Fund for allowance of purchasing a work. This procedure was too slow, and Hermann Goetz complained in his letter that he had missed out on opportunities of buying pieces. His suggested solution was to have more autonomy to be able to buy works up to 1000rs on his own responsibility within a fixed budget. ${ }^{\mathrm{xV}}$

In a second letter dated in November 1953 he further comments on his first letter and explains why he is unable to execute purchases. The committee was based on members from different parts of India, who had to appear physically in Delhi to make decisions, whether an artwork should be purchased or not. Therefore, Goetz had to gather many offers before the members arranged a meeting. This led to the fact that only works offered by speculators could be shown to the committee:

"When I select a picture or other work in exhibitions, the artists agree only under the condition that I may have it for offer to the Purchase Committee, in case nobody else buys it on the spot. But the really good and in this case also still comparatively cheap works are almost always sold to some embassy or private person before the exhibition is over." xvi

and secondly:

"When I request artists, even well-known ones, to make offers, I again obtain, in most cases, just those works which the artist could not sell, i.e. generally his less successful creations. And from private side only very few offers worth consideration have hitherto been received. How under these circumstances we shall be able soon to build up a National Art Gallery, I cannot see." xvii

Goetz letters reflect the difficulties he had to build up the collection and how being under a direct mandate of the government slowed down the process. His idea to solve the problem summons his understanding of the situation and suggests being allowed to buy pieces worth up to 1000rs on his own responsibility. Furthermore, he requests the government to set up a small purchase committee in Delhi consisting of local members that can react ad hoc and decide over more expensive works. He suggests similar committees for Calcutta, Bombay, Madras and eventually also Lucknow, Hyderabad, and Bangalore. Once a year a general meeting of all committees should be called in. He names several people for the committee. .viii

In return the deputy of the Secretary Mr. Vikram Singh answers on the $24^{\text {th }}$ December 1953, that he had never received any proposal to purchase a work. Yet he inquires with other leading heads of the country whether he should give Goetz the permission and all of them agree, whereupon in April Goetz receives a letter about the same.

In the following letters the requested people all agree to being members of the local committees, but it is unclear who decided on the selection. Presumably it had been Vikram Singh, who had decided on this. Meanwhile the local committees must have gotten together and already suggested a number of works, not to Hermann Goetz's satisfaction, since he writes in a letter to Vikram Singh on the $4^{\text {th }}$ June 1954 , that he is "not impressed at all by the selection" and that he doubts "whether most of the pictures are suitable for exhibition." "xix Surprisingly Goetz reports that he is not a member of the local committee and that he does not even know the names of the members of the local committees. It seems that the ministry of education compromised their decision by excluding Goetz of purchase decisions. Therefore, the autonomy Goetz had fought for, was entirely taken from him and given to a committee he could not engage with.

His question about the members of the committee gets answered only through the state of Hyderabad, sending a list with the names of all members of the local committee in Hyderabad. The missing answers might be lost or Hermann Goetz never received such answers. Through the acquisition files it unfortunately becomes obvious, that state politics and slow bureaucracy slowed down the process and attempt of Hermann Goetz to build up a collection for the gallery. 
7 | In transition: Collection building at the National Gallery of Modern Art in New Delhi

Furthermore, here the problems the gallery is still facing today unravelled for the first time: Being under a direct mandate of the government, doesn't allow the director of the gallery to make decisions, purchase work and even curatorial decisions are coloured by state interventions.

Nevertheless, during these years, the collection of the gallery grew, again through artist's relatives, who offered entire bodies of work to the institution. In 1955, about 102 paintings by Rabindrananth Tagore were given to the gallery by his son. In return he requested Rs. 50.000, which were again taken from the National Museum's fund.

In the early years of the gallery exhibitions that were held were based on this collection. The institution was therefore built up upon cultural capital, rather than monetary capital, being completely dependent on donors who might have been attracted by seeing their works, or close relatives works in upcoming national institutions.

The collection of the National Gallery of Modern Art was from its beginning in 1954 until today's time mainly based on chance rather than systematically collecting of artworks. Unlike in its beginning, when the first director Hermann Goetz searched for works that would represent creative practice in India, later works were offered to the gallery and the purchase committee decided whether works can be afforded or not. Other works and entire collections were simply gifted. In today's time works are not purchased anymore due to fiscal limitations, limitations and perhaps the anxiety of interfering with the marked and being accused of favourism of artists and galleries.

\section{Notes}

' Foucault, Michel: The Archaeology of Knowledge, Pantheon Books, New York, 1969.

ii Derrida, Jacques, and Eric Prenowitz: Archive Fever: A Freudian Impression, Chicago: University of Chicago Press, 1996, p. 2.

iii Altshuler, Bruce: 'A Canon of Exhibitions', in: Manifesta Journa/ No. 11, 2010/2012, p. 5.

iv Huyssen, Andreas: 'Geographies of modernism in a globalizing world', in: Geographies of Modernism Literatures, cultures, spaces, edited by Peter Brooker and Andrew Thacker, Routledge, New York, 2005, p. 7.

${ }^{v}$ Letter from Hoare to Willingdon, 8th December 1933, Willingdon Papers, European Manuscripts, E240/3, National Archives.

vi Shivadas, Vidya: 'Museumising modern art, National Gallery of Modern Art: The Indian case-study', in: No touching, no spitting, no praying, The Museum in South Asia, edited by Saloni Mathur and Kavita Singh, Routledge, 2014, p. $149-170$.

vii Author Unknown: 'An Appeal for Public Support for a National Art Gallery', Roopa-Lekha, Vol. 1, No. 2 (1940), p. 2.

viii Note by Ashfaque Husain, Secretary, Ministry of Education dated 23/4/48, Purchase of Paintings of Amrita Sher-Gil, 27A/19/48, ASI RR.

ix Note from Ram Gopal, Ministry of Finance to Janak Kumari Asghar, Secretary of the Ministry of Education dated 20/9/48, Purchase of Paintings of Amrita Sher-Gil, 27A/19/48, ASI RR.

× Shivadas, 2014, pp. $149-170$.

${ }^{x i}$ List of paintings of National Art Gallery, Archeological Survey of India Archive: Section/25/7/53.

xii Lochan, Rajeev: 'Introduction', in: Treasures of the Collection of the National Gallery of Modern Art, Unpublished essay, 2013.

xiii Jettmar, Karl: 'Hermann Goetz', in: East and West, Nr. 26, 1976, p. 540.

xiv Jain-Neubauer, Jutta: 'Did you know that... one of the pioneers of the museum movement in India was a German?' for the German Embassy, article online: 
http://www.india.diplo.de/Vertretung/indien/en/13_Culture/Bilaterals/Did_you_know/Hermann_Goetz. html

${ }^{x v}$ Letter from Hermann Goetz to the Ministry of Education, National Archives, File: D 7833/53-H.2.

xvi Letter from Hermann Goetz to the Ministry of Education, National Archives, File 8356/53-H.2.

xvii Ibidem.

xviii Ibidem.

xix Letter from Hermann Goetz to Vikram Singh, National Archives, FS-60/54-H.2.

Arnika Ahldag is the associate curator at MAP. As an art historian, she investigates the representation of labour in Indian contemporary art. Her curatorial projects include the public programme for IAF 2020 and Mapping Gender: Bodies and Sexualities in the Global South at the Jawaharlal Nehru University. As an artist she works in video and performance and her recent projects were shown at the Bhubaneswar Art Trail, the Kiran Nadar Museum of Modern Art and Max Mueller Bhavan, New Delhi. She co-founded the Feminist Syllabus, which is part of the workshop series Pact of Silence, How to break it, a programme for intersectional feminist discourses in the arts. Over the past years she lectured at the National School of Drama and OP Jindal Global University in New Delhi. She is a PhD candidate at JNU and holds an MA from University College in London, UK and Albert Ludwigs University in Freiburg, Germany. 